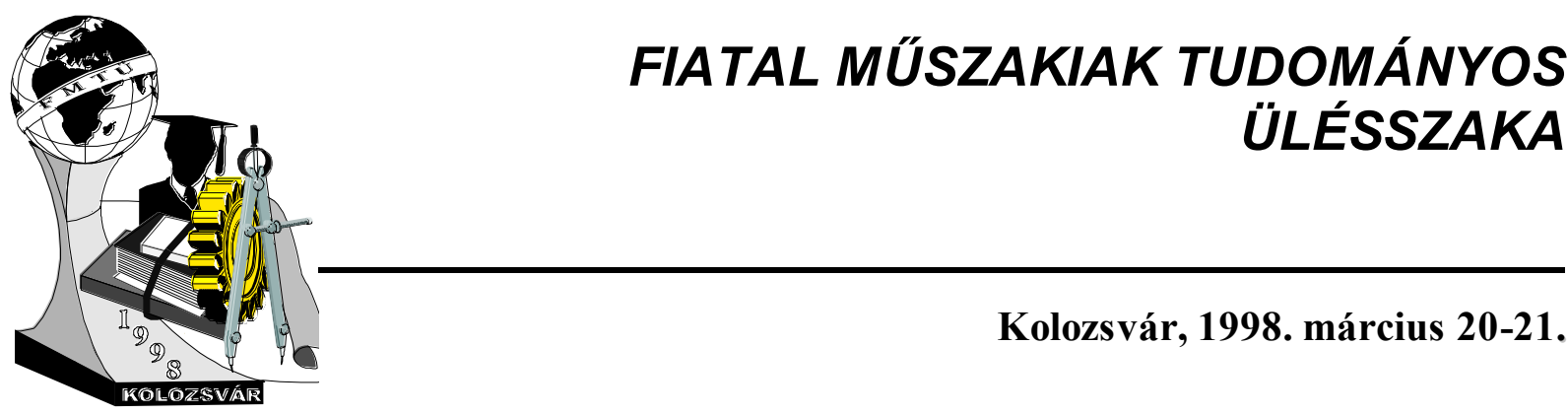

\title{
Képlékeny alakváltozás során bekövetkezett üregegyesülés kísérleti elemzése
}

\begin{abstract}
Kovács Rita ${ }^{1}$
\section{Abstract}

In this work an experimental overview of cavity coalescence processes will be presented. The main objective of the present research will be the elaboration of a unified fracture criterion for ductile materials exhibiting large plastic deformation. For this purpose three different loading cases will be considered: high temperature creep and low cycling fatigue of steel, and room temperature tensile test of aluminium. The importance of some physical parameters, as the temperature and strain rate on the cavity coalescence mechanics have been underlined.
\end{abstract}

\section{Bevezetés}

Az elmúlt években a képlékenységtan egyik legfontosabb fejlesztési iránya a kompozit anyagok alakváltozásának mechanikai leírása volt. A jelenleg egyik legelterjedtebben alkalmazott módszer PONTE CASTAŃEDA (1992) nevéhez füződik, aki a mikromechanikai modellezés klasszikusnak számító variációs elveinek alkalmazhatóságát terjesztette ki nemlineáris anyagokra. Ezen variációs elvek segítségével lehetővé válik ismert mikroszerkezet esetében a nem lineáris összetevőkből felépülő anyagot jellemző anyagtörvény, illetőleg az ehhez kapcsolódó folyási felület kidolgozása. Az új variációs elvek előnye, hogy a már régóta ismert lineáris anyagegyenletekből származtatja a nemlineáris anyagegyenletet, nagymértékben egyszerüsítve így a munkát.

Ugyanakkor a fentiekben említett variációs elvek nem tartalmaznak semmilyen, az alakváltozás behatárolását lehetővé tevő feltételt. Célszerünek tünik az üregesedési károsodás végső fázisának elemzése, az eredmények beillesztése az anyagmodellbe. Az üregegyesülés szakaszának vizsgálatával számos szerző foglalkozott, illetve dolgozott ki egyesülési mechanizmus leírására elméleti modellt. Nem foglalkoztak azonban általában az üregegyesülési mechanizmusok hőmérséklet, terhelési módtól való függésével.

Jelen munka célja olyan támpontok keresése, amely lehetővé teszi az üregegyesülési mechanizmusok összefoglaló kezelését és egységes leírási módját, illetőleg egyesülési térképek készítését. Ezen térképek az Ashby (ASHB-GANDHI-TAPLIN, 1979) által kidolgozott törési térképekhez hasonló felépítésủek lehetnek.

\footnotetext{
${ }^{1}$ Ph.D. hallgató, Miskolci Egyetem, Mechanikai Technológiai Tanszék

Tudományos vezető: Prof. Dr. Tisza Miklós, tanszékvezető egyetemi tanár
} 


\title{
Kísérleti eredmények
}

A kísérleti munka során a törést közvetlenül megelőző üregegyesülési szakasz elemzését tűztük ki célul. A vizsgálatokhoz a Miskolci Egyetem Mechanikai Technológiai Tanszékén lévő TESLA gyártmányú scanning-elektron mikroszkópot használtuk. Az elvégzett vizsgálatok közül a következőkben három jellegzetes példát mutatunk be.

\section{Alumínium próbatest szakítóvizsgálata}

Az 1. ábra alapján látható, hogy a repedés akkor jelenik meg, amikor a két üreg távolsága egy minimális határ alá csökken. Az üregegyesülés akkor következik be, amikor az üregek közötti „,anyaghíd” nem áll tovább ellent a külsõ terhelõ erõnek.

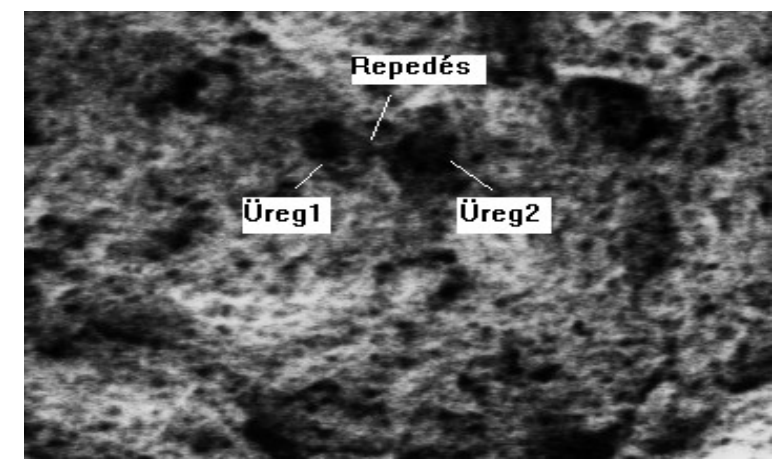

a/

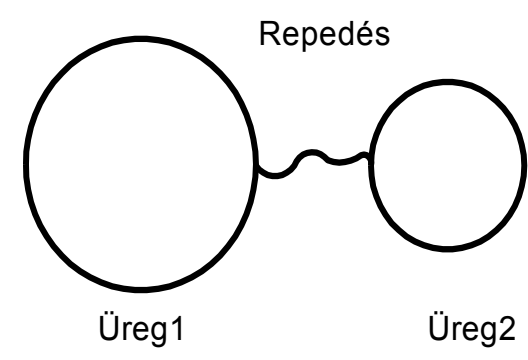

b/

\author{
1. ábra \\ Aluminium próbatest szakitóvizsgálatánál fellépő üregegyesülés \\ a/ Elektron mikroszkópos felvétel, b/ Elméleti modell
}

Az üregesedési károsodás során kialakult üregek távolságát a létrejöttükkor szerepet játszó zárványok távolsága határozza meg. Az üregek felületének távolsága folyamatosan csökken az üregnövekedés során. Vagyis az anyaghíd vastagsága, így a törési feltétel is az üregnövekedés és az üregek kialakulásakor fontos zárványok távolságának is függvénye.

\section{Kúszásvizsgálat}

A 2. ábra alapján látható, hogy a repedés, az előző mechanizmushoz hasonlóan két üreg között jelenik meg. A két üregegyesülés közötti jelentős különbség abban áll, hogy amíg alacsony hőmérsékleten az először kialakult üregek növekednek, és gyakorlatilag „összenőnek”, addig kúszás során a viszonylag kis üregek között kialakuló feszültségkoncentráció újabb üregek létrejöttét indukálja. A repedés végül a kis üregek összenövésével alakul ki. 


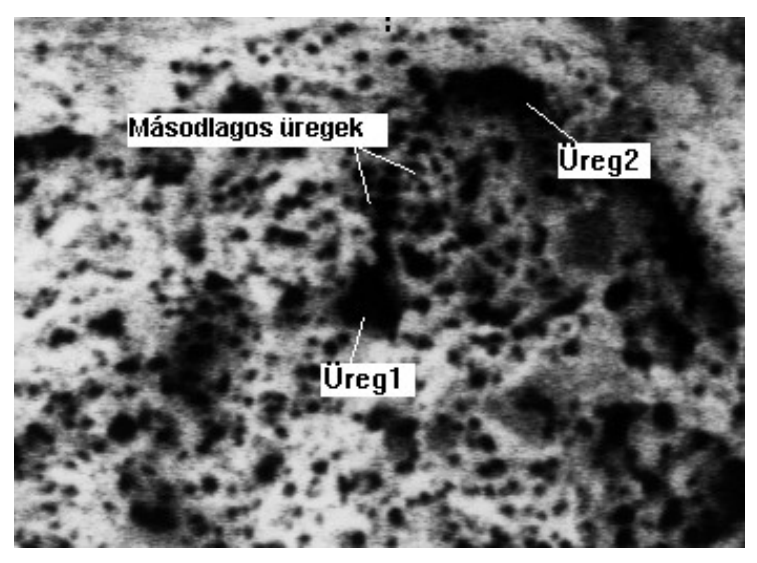

a/

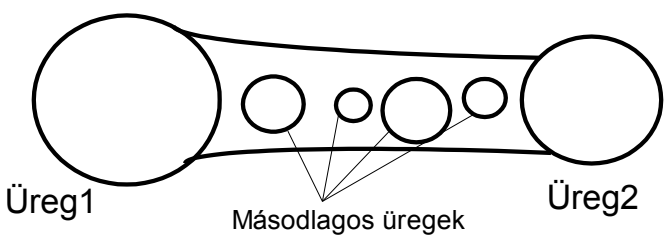

b/

\section{2.ábra}

Kúszásvizsgálat során létrejövő üregegyesülés a/ Elektron mikroszkópos felvétel, b/ Elméleti modell

A fentiek alapján látható, hogy kúszás esetében a törési feltételnek mind az üregek növekedési, mind a keletkezési mechanizmusától függnie kell.

\section{Kis ciklusú fáradás}

Ismétlődő terhelés esetében, amennyiben az anyag szívósan viselkedik, a repedés általában egy különálló üregből indul el - 3. ábra. Ennek oka, hogy a már kialakult üreg az adott terhelésmód mellet - a húzóterhelést nyomó követi - nem növekszik. Ugyanakkor az üreg nagy ciklusszám mellet bemetszésként viselkedik, vagyis a repedéskeletkezést elősegítheti.

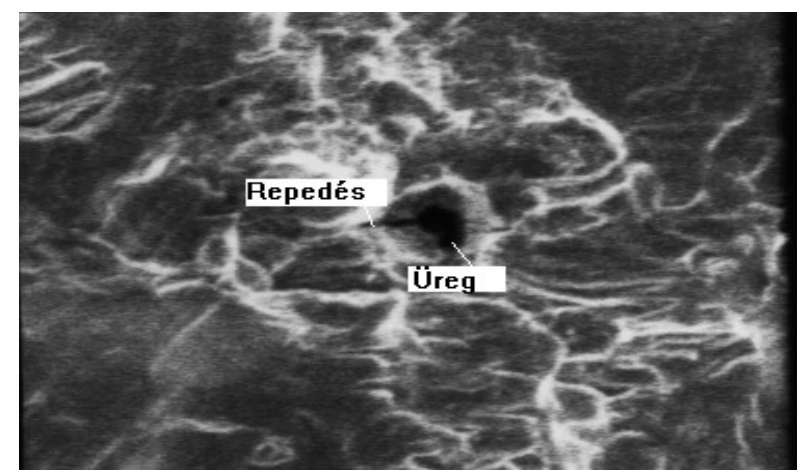

a/

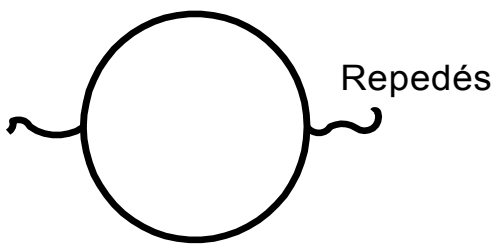

Üreg

3.ábra

Kisciklusú fáradás esetén fellépö repedésterjedés a/ Elektron mikroszkópos felvétel, b/ Elméleti modell 
A fentiek jelzik az üregegyesülési módok komplex, hőmérséklet - terhelés függését. Jól mutatják azt is, hogy egységes törési feltétel kidolgozásakor számos paraméter hatását figyelembe kell venni: terhelés, hőmérséklet, a diffúziós állandó, üregnövekedést és keletkezést befolyásoló paraméterek, stb.

Ilyen nagyszámú paraméter egységes kezelésére az irodalomban két hatékonynak tünő eljárás ismert: szakértői - mesterséges intelligencia rendszerek alkalmazása, illetőleg az Ashby (ASHBY-GANDHI-TAPLIN, 1979) által javasolt törési térképekhez hasonló elven müködő diagramok szerkesztése.

Az eddigi elemzések alapján javasolhatónak tünik a szívós törés egyes mechanizmusai közötti választásra „Üregegyesülési térkép” bevezetése. Ezen térkép eltérő anyagok esetében is lehetővé teheti az eltérő terhelési módok egységes kezelését.

\section{Összefoglalás}

Jelen munka célja a képlékeny törést közvetlenül megelőző mechanizmusnak, az üregesedési károsodás üregegyesülési szakaszának irodalmi és kísérleti elemzése volt. Az eredmények alapján az alábbi következtetéseket vonhatjuk le:

1. Az irodalmi kutatások alapján megállapítható, hogy az üregek egyesülésének leírására nem létezik olyan modell, mely figyelembe veszi a legfontosabb paraméterek - alakváltozási sebesség, hőmérséklet, stb. - hatását, az adott paramétercsoport esetében lejátszódó mechanizmus kiválasztását.

2. A kísérleti eredmények alapján látható, hogy az egyes üregegyesülési mechanizmusok adott terhelési módok esetében és adott hőmérsékleten jelentkeznek. Célszerünek látszik a legfontosabb paraméterek felhasználásával az ASHBY-féle törési térképekhez hasonló üregegyesülési térkép kidolgozása.

\section{Irodalom}

[1] Ponte Castańeda P., J. Mech. Phys. Solids, V40 No.8, pp.1757-1788, 1992

[2] Ponte Castańeda P.- Zaidman, J. Mech. Phys. Solids, V42 No.9, pp.1459-1497, 1994

[3] Ashby- Gandhi- Taplin, Acta. Metall. Mater. V27, pp.699-729, 1979

Kovács Rita doktorjelölt

Miskolci Egyetem, Mechanikai Technológiai Tanszék

Tel.: 06-46-365111-1846 